\title{
Erratum to: The role of pro-inflammatory S100A9 in Alzheimer's disease amyloid-neuroinflammatory cascade
}

\author{
Chao Wang • Alexey G. Klechikov • Anna L. Gharibyan · Sebastian K. T. S. Wärmländer • \\ Jüri Jarvet • Lina Zhao $\cdot$ Xueen Jia $\cdot$ Vinod K. Narayana $\cdot$ S. K. Shankar · Anders Olofsson • \\ Thomas Brännström · Yuguang Mu • Astrid Gräslund $\cdot$ Ludmilla A. Morozova-Roche
}

Received: 9 April 2014 / Revised: 26 June 2014 / Accepted: 26 June 2014 / Published online: 17 July 2014

(C) Springer-Verlag Berlin Heidelberg 2014

Erratum to: Acta Neuropathol (2014) 127:507-522

DOI 10.1007/s00401-013-1208-4

The authors wish that Mr. Vinod K. Narayana should serve as an additional author in the 8th position as he had been inadvertently omitted as an author in the original paper.
The online version of the original article can be found under doi:10.1007/s00401-013-1208-4.

C. Wang · A. G. Klechikov · A. L. Gharibyan · X. Jia ·

V. K. Narayana $\cdot$ A. Olofsson $\cdot$ L. A. Morozova-Roche $(\square)$

Department of Medical Biochemistry and Biophysics,

Umeå University, 90187 Umeå, Sweden

e-mail: ludmilla.morozova-roche@medchem.umu.se

S. K. T. S. Wärmländer · J. Jarvet · A. Gräslund Department of Biochemistry and Biophysics, Stockholm University, 10691 Stockholm, Sweden

J. Jarvet

National Institute of Chemical Physics and Biophysics,

Akadeemia tee 23, 12618 Tallinn, Estonia

L. Zhao $\cdot$ Y. Mu

School of Biological Sciences, Nanyang Technological

University, 60 Nanyang Drive, Singapore, Singapore
Present Address:

V. K. Narayana

No: 25/A, 20th Main, Banashankari 1st Stage, Behind PES

College, Srinagar, Bangalore 560050, Karnataka, India

S. K. Shankar

Human Brain Tissue Repository, Department of Neuropathology,

National Institute of Mental Health and Neurosciences,

Bangalore 560029, India

T. Brännström

Department of Medical Biosciences, Umeå University, 90187 Umeå, Sweden 